\title{
Evaluasi Program English Massive Dalam Upaya Peningkatan Kapasitas Masyarakat di Kota Kediri Tahun 2017-2019
}

\author{
Evaluation Of English Massive Program In Efforts To Increase \\ Community Capacity In Kediri City 2017-2019
}

\author{
Anselmus Edwin Dwi Cahya ${ }^{1,}$, Rizqi Bachtiar ${ }^{2}$ \\ ${ }^{1-2}$ Program Studi Ilmu Pemerintahan, FISIP, Universitas Brawijaya \\ Email Korespondensi: edwinanselmus2204@gmail.com
}

\begin{abstract}
Abstrak
Penelitian ini bertujuan untuk mengetahui pelaksanaan program English Massive (E-Mas) dalam upaya peningkatan kapasitas masyarakat di Kota Kediri tahun 2017-2019 dengan teori Evaluasi model CIPP menurut Stufflebeam diantaranya: Context; Input, Process, Product. Penelitian ini menggunakan metode penelitian kualitatif deskriptif. Subjek penelitian diantaranya penyelenggara program, partisipan, tutor dengan menggunakan teknik purposive. Hasil Penelitian menunjukkan evaluasi program English Massive berdasarkan: Context, latar belakang dan tujuan ialah ingin memberdayakan masyarakat melalui pembelajaran Bahasa Inggris supaya meningkatkan daya saing dan kapasitas masyarakat kota Kediri; syarat E-Mas mudah dan target sasaran seluruh warga Kota Kediri. Input, kesesuaian partisipan telah sesuai namun hanya kategori children memiliki jumlah partisipan tiggi; Tutor disediakan oleh Dinas Pendidikan dan sesuai dengan kriteria namun jumlah tutor menurun; materi yang diberikan sesuai dengan silabus dan kemampuan partisipan dengan fokus conversation dan speaking; anggaran telah mencukupi untuk kebutuhan dan operasional program; sarana dan prasarana sudah cukup memadai karena dikelola oleh masyarakat sendiri; informasi sudah jelas diberikan melalui sosialisasi, media sosial dan internet. Process, penjadwalan telah sesuai sebab jadwal direncanakan oleh partisipan dan tutor; proses pembelajaran cukup efektif melalui diskusi dan fun game; aktivitas selain pembelajaran yaitu outing class, COIN EMAS, outbond dan sebagainya; hambatan yaitu kesadaran masyarakat kurang, adanya kesibukan, spot kurang kondusif, jarak yang jauh antara spot dengan tempat tinggal tutor, honor tidak cair tiap bulan, modul tidak dibagikan ke partisipan. Product, dampak yang dirasakan partisipan adanya peningkatan kemampuan partisipan dalam berbahasa inggris; meningkatkan IPM Kota Kediri.
\end{abstract}

Kata kunci: Evaluasi, English Massive, Masyarakat

\begin{abstract}
This study aims to investigate the implementation of the English Massive (E-Mas) program as an effort to improve social capacity in Kediri City, year 2017-2019 by utilising Stufflebeams's theory of evaluation. This research uses descriptive qualitative research methods. Research subjects include program organizers, participants, tutors by using purposive techniques. The results of the study show that the background and purpose of the English Massive program based on the first indicator in which Context is
\end{abstract}


to empower the society through learning English in order to improve the competitiveness and capacity of the Kediri's citizens; E-Mas requirements are easy and target for all residents of Kediri City. Based on Input Indicator, participants are arguably fit with the standar but only the children category has a high number of participants; Tutors were provided by the Education Office (Dinas Pendidikan); the material provided is in accordance with the syllabus and the ability of participants focusing on conversation and speaking. The budget is sufficient for program's expenses and operations; facilities and infrastructure are good enough because they are managed and provided also by the society itself; information has clearly been provided through outreach, social media and the internet. Based on Process Indicator, scheduling is appropriate because the schedule is planned by participants and tutors; the learning process is quite effective through discussion and fun games; activities other than learning, namely outing class, COIN EMAS, outbound and so on; the obstacles are lack of public awareness, busyness, less conducive spot, long distance between spot and tutor's residence, monthly non-payment of honorarium, modules are not distributed to participants. Product Indicator, the impact felt by the participants is an increase in the ability of participants in speaking English as well as improving the HDI of Kediri City.

Keywords: Evaluation, English Massive, Society

\section{Pendahuluan}

Pendidikan merupakan bagian terpenting dalam membangun sebuah bangsa yang mampu bersaing secara global. Tujuan dengan adanya pendidikan yaitu untuk membantu setiap individu atau kelompok untuk mengembangkan potensi dan kemampuan yang dimiliki. Sesuai dengan Undang-undang Republik Indonesia Nomor 20 Tahun 2003 tentang Sistem Pendidikan Nasional (SISDIKNAS) telah dijelaskan bahwasannya salah satu fungsi Pendidikan nasional adalah untuk mengembangkan kemampuan peserta didik. Maka dari itu penting setiap masyarakat memperoleh pendidikan agar mereka dapat meningkatkan kualitas sumber daya manusia sehingga mampu bersaing serta mendapat pengetahuan yang lebih.

Pendidikan diselenggarakan sebagai bentuk dari proses pemberdayaan peserta didik. Hal tersebut diperkuat dengan adanya prinsip dalam penyelenggaraan pendidikan yang tercantum pada pasal 4 dalam UU Sisdiknas bahwasannya pendidikan diselenggarakan dengan cara memberdayakan seluruh komponen masyarakat melalui peran dalam penyelenggaraan dan pengendalian mutu layanan pendidikan. Oleh sebab itu pendidikan tidak dapat dipisahkan dari hal yang berkaitan dengan pemberdayaan sebab keduanya saling dilakukan secara bersama.

Pendidikan sangat diperlukan untuk mengembangkan potensi yang ada, salah satunya melalui pendidikan keterampilan. Di era globalisasi ini untuk dapat bersaing secara global maka diperlukan kemampuan dalam menguasai Bahasa asing terutama 


\section{Cahya dan Bachtiar: "Evaluasi Program English Massive Dalam Upaya Peningkatan Kapasitas Masyarakat di Kota Kediri Tahun 2017-2019"}

Bahasa inggis sebab Bahasa inggris dijadikan sebagai Bahasa internasional. Indonesia merupakan salah satu negara yang termasuk dalam daftar yang memiliki kecakapan rendah dalam penguasaan Bahasa inggris. Berdasarkan data EF yang terbaru pada 2019 (First, 2019), Indonesia masuk dalam peringkat 61 dari 100 negara dengan presentase indeks kecakapan Bahasa inggris mencapai 50,06. Maka dari itu perlu adanya gebrakan oleh pemerintah khususnya untuk membuat sebuah kebijakan yang dapat melatih masyarakat Indonesia dalam menggunakan Bahasa asing terutama Bahasa inggris.

Salah satu daerah yang memiliki sebuah program pelatihan atau pembelajaran Bahasa inggris ialah Kota Kediri. Dengan adanya program tersebut harapannya masyarakat dapat memiliki kemampuan dalam berbahasa inggris dan berdampak pada meningkatnya indeks pembangunan manusia (IPM) di Kota Kediri. Program tersebut dibuat sebagai bentuk kepedulian pemerintah daerah kota Kediri dalam meningkatkan Sumber Daya Manusia (SDM) agar mempu bersaing. Program tersebut bernama English Massive (E-Mas) yang bertujuan untuk memperbaiki atau meningkatkan kualitas SDM Kota Kediri melalui pelatihan Bahasa inggris serta menyebarluaskan dan memperkenalkan kepada masyarakat Kota Kediri terkait penggunaan Bahasa inggris.

Program E-Mas merupakan program dibawah kendali dari Dinas Pendidikan Kota Kediri yang berbasis masyarakat dan di desain seperti pemberdayaan masyarakat. Kegiatan E-Mas ialah berupa pelatihan atau pembelajaran Bahasa inggris di tingkat RT yang diberikan secara gratis kepada seluruh masyarakat. Program E-Mas merupakan program inisiatif dari pemerintah Kota Kediri yang bertujuan untuk mensukseskan program pemberdayaan masyarakat (Prodamas). Sesuai dengan salah satu poin yang terdapat pada PERWALI Nomor 40 Tahun 2014 tentang Program Fasilitasi Pemberdayaan Masyarakat telah dijelaskan bahwa prodamas bertujuan untuk melaksanakan kegiatan pembangunan masyarakat sebagai upaya mewujudkan kemampuan dan kemandirian masyarakat. Selain untuk mensukseskan prodamas, program ini disiapkan untuk mendukung program pendidikan agar menciptakan dan mempersiapkan SDM di Kota Kediri untuk menghadapi persaingan dalam masyarakat ekonomi ASEAN.

Program E-Mas diberikan secara gratis kepada seluruh masyarakat tanpa batasan usia, namun tetap ada persyaratan untuk dapat mengikuti program tersebut. salah satunya ialah mengajukan permohonan kepada Dinas Pendidikan Kota Kediri dan dalam mengajukan tersebut sudah terdapat kelompok yang berisi partisipan serta penanggung jawab spot. Dalam program tersebut, terdapat pengelompokan berdasarkan umur yaitu mulai dari kalangan anak kecil seperti TK dan SD, kemudian remaja SMP hingga SMA dan dewasa seperti mahasiswa serta masyarakat yang sudah tidak duduk di bangku 
sekolah. Tujuannya ialah agar materi yang disampaikan sesuai dengan apa yang dibutuhkan setiap partisipan. Dalam proses pembelajaran Dinas Pendidikan Kota Kediri beserta Tim Manajemen E-Mas telah menyediakan tutor yang berkompeten untuk menyampaikan materi. Tutor yang disediakan tersebut diperoleh dari proses rekrutmen terlebih dahulu. Selain kegiatan pembelajaran di spot, Dinas Pendidikan Kota Kediri dan Tim Manajemen E-Mas juga menyelenggarakan perlombaan atau kompetisi yang bernama COIN E-Mas yang bertujuan untuk mengukur sejauh mana kemampuan partisipan dalam menguasai Bahasa inggris.

Program ini merupakan program yang diberikan secara gratis dan mengutamakan adanya partisipasi dari masyarakat agar program dapat berjalan dengan baik. Namun pada pelaksanaannya berdasarkan data jumlah partisipan mengalami penurunan.

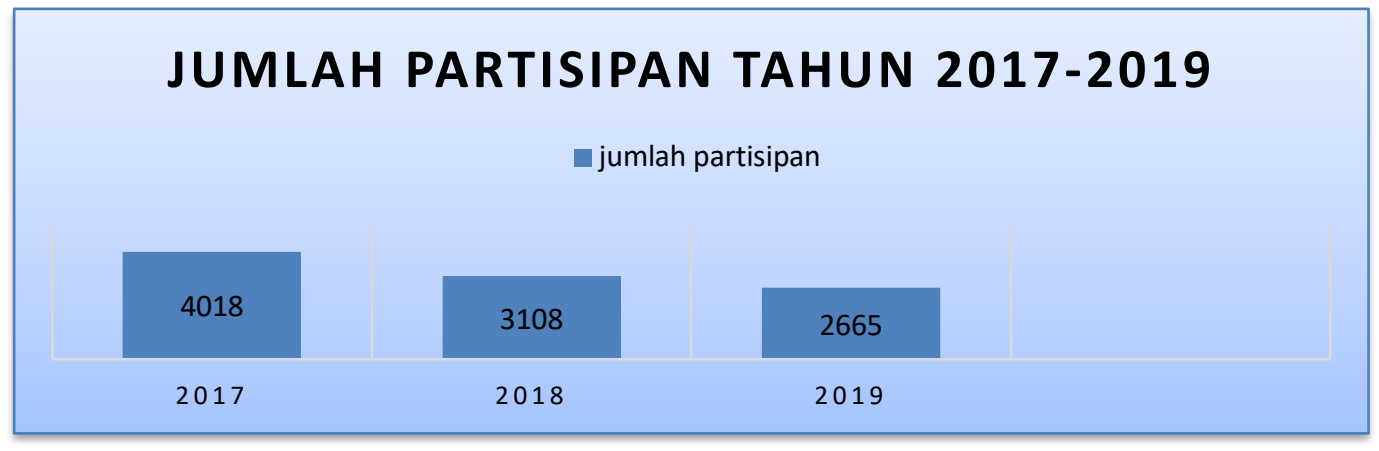

Grafik 1

Jumlah Partisipan English Massive Tahun 2017 - 2019

Sumber: Olahan Hasil Penelitian (2019)

berdasarkan grafik 1 bahwa jumlah partisipan yang tinggi terjadi pada tahun 2017 mencapai 4018 partisipan. Namun pada tahun berikutnya mengalami penurunan terhadap jumlah partisipan. Pada tahun 2018 data menunjukkan jumlah partisipan menurun menjadi 3108 partisipan dan pada tahun 2019 menjadi 2665 partisipan. Terjadinya penurunan tersebut menjadi permasalahan dan perlu diatasi oleh Dinas Pendidikan Kota Kediri dan Tim Manajemen E-Mas guna mendapatkan solusi untuk meningkatkan jumlah partisipan program E-Mas. Selain menurunnya jumlah partisipan, berdasarkan penelitian sebelumnya yang dilakukan oleh Martina (Diah, 2018) bahwasannya jumlah tutor yang tersedia masih kurang memadai dengan jumlah partisipan yang ada.

Selain hal tersebut, pengelompokkan yang masih menggunakan kategori umur juga menjadi permasalahan dalam mengukur sebuah keberhasilan. Hal tersebut dikarenakan apabila terdapat partisipan yang telah mengikuti selama 3 tahun berturut-turut kemudian digabungkan dengan partisipan yang belum pernah mengikuti justru akan timbul rasa jenuh sebab terjadi pengulangan materi yang sama. Selain menimbulkan rasa jenuh akibat pengulangan materi, pengelompokkan yang masih menggunakan kategori umur akan 


\section{Cahya dan Bachtiar: "Evaluasi Program English Massive Dalam Upaya Peningkatan Kapasitas Masyarakat di Kota Kediri Tahun 2017-2019"}

berdampak pada tidak memungkinkannya adanya peningkatan ke level yang lebih tinggi untuk mendapatkan materi yang lebih, sebab apabila ingin mendapatkan materi yang lebih maka harus masuk kategori umur selanjutnya.

berdasarkan latar belakang permasalahan diatas maka perlu adanya kajian terhadap program E-Mas agar mendapatkan informasi terbaru. Kajian tersebut sangat penting untuk mengetahui faktor pendukung dan penghambat selama pelaksanaan dan kemudian menghasilkan sebuah rekomendasi yang berguna untuk perbaikan program E-Mas agar program tersebut dapat ditingkatkan menjadi lebih baik. Maka dari itu, dalam penelitian ini akan mengkaji bagaimana evaluasi program English Massive dalam upaya peningkatan kapasitas masyarakat di Kota Kediri pada tahun 2017-2019.

\section{Metode Penelitian}

Metode penelitian yang digunakan pada penelitian ini ialah metode penelitian kualitatif deskriptif. Menurut Sutopo dan Arief (Suwendra, 2018), penelitian kualitatif adalah mendeskripsikan dan menganalisa fenomena, peristiwa, aktivitas sosial, sikap, kepercayaan, persepsi, pemikiran orang secara individual maupun kelompok; kegiatan terencana untuk menangkap praktek penafsiran responden atau informan terhadap dunianya yang selalu majemuk, berbeda dan dinamis; bersifat menggambarkan, mengungkapkan dan menjelaskan. Fokus penelitian ini ialah evaluasi program English massive di Kota Kediri tahun 2017-2019. Penelitiaan ini dilakukan di Kota Kediri tepatnya di Dinas Pendidikan Kota Kediri dan Spot belajar English massive.

Kemudian untuk jenis data yang digunakan pada penelitian ini ialah jenis data primer dan sekunder. Teknik penentuan informan menggunakan teknik purposive yang berarti informan telah ditentukan dengan pertimbangan dan tujuan tertentu. Pengumpulan data melalui wawancara, observasi dan dokumentasi. Teknik analisa data pada penelitian ini menggunakan teknik analisa data kualitatif berdasarkan konsep dari Miles \& Huberman yaitu melakukan pengumpulan data di lapangan, selanjutnya reduksi data, penyajian data dan kemudian penarikan kesimpulan.

\section{Kerangka Teori}

\section{Analisis Kebijakan Publik}

Analisis kebijakan publik menurut Walter William (Nugroho, 2017) adalah suatu upaya memberikan informasi, dimana hasil-hasil penelitian berguna untuk menghasilkan suatu bentuk keputusan kebijakan. Kemudian berbeda dengan Walter, menurut William Dunn (Nugroho, 2017) analisis kebijakan publik ialah suatu kegiatan intelektual dan rasional yang bertujuan membentuk, teliti dalam mengukur dan mengemukakan pengetahuan yang ada dalam proses sebuah kebijakan. Berdasarkan beberapa penjelasan 
terkait analisis kebijakan publik maka dapat ditarik sebuah kesimpulan bahwasannya analisis kebijakan publik merupakan sebuah kegiatan yang menghasilkan sebuah data atau informasi yang diinginkan, dimana berupa penilaian dan menjelaskan sebuah pengetahuan dalam proses kebijakan. William Dunn mengatakan bahwa dalam analisis kebijakan publik terdapat beberapa tahap diantaranya perumusan masalah, peramalan, rekomendasi, pemantauan, dan penilaian.

\section{Evaluasi Kebijakan}

Evaluasi kebijakan sering disebut dengan penilaian kebijakan merupakan salah satu langkah terakhir dalam melaksanakan kegiatan proses analisis kebijakan. Menurut Jones (Islamy, 2009) evaluasi kebijakan adalah suatu kegiatan yang telah disusun dengan tujuan untuk melakukan penilaian dari hasil berbagai macam program-program pemerintah dimana memiliki berbagai perbedaan yang penting dalam objeknya, cara pengukuran serta teknik analisis. Sedangkan menurut Spaulding (Agustino, 2017) evaluasi kebijakan merupakan serangkaian kegiatan yang telah disusun dimana bertujuan untuk menyelesaikan permasalahan dengan cara yang tepat.

Sementara itu Stufflebeam (Stufflebeam, 1985) mengatakan bahwa evaluation is the process of delineating, obtaining, and providing descriptive and judgemental information about the worth and merit of some object's goals, design, implementation, and impact in order to guide decision making, serve needs for accountability, and promote understanding of the involved phenomena. Yang berarti evaluasi adalah proses untuk menyediakan informasi yang dijadikan penilaian atau pertimbangan dalam menetapkan nilai dan manfaat dari tujuan yang diinginkan, desain, implementasi dan dampak yang dapat membantu dalam membuat sebuah keputusan, pertanggung jawaban dan pemahaman fenomena yang terjadi. Model evaluasi yang dikembangkan oleh Stufflebeam yaitu evaluasi model CIPP, CIPP merupakan kepanjangan dari context, input, process dan product.

\section{Evaluasi Model CIPP Stufflbeam}

Evaluasi model CIPP yang dikembangkan oleh Stufflebeam ialah salah satu model evaluasi yang sering digunakan oleh para evaluator untuk mengevaluasi suatu program salah satunya program pendidikan. Evaluasi model CIPP memiliki pandangan bahwa keberhasilan suatu program tidak hanya dipengaruhi oleh satu atau dua faktor saja melainkan terdapat beberapa faktor yang saling mempengaruhi. tujuan evaluasi terdapat 3 menurut pandangan dari Stufflebeam (Rusdiana, 2017) diantaranya yaitu pertama menyediakan dan menetapkan sebuah informasi yang memiliki manfaat untuk menilai 


\title{
Cahya dan Bachtiar: "Evaluasi Program English Massive Dalam Upaya Peningkatan Kapasitas Masyarakat di Kota Kediri Tahun 2017-2019"
}

keputusan alternatif; kedua untuk membantu audience guna memberikan penilaian dan melakukan pengembangan manfaat suatu program pendidikan atau objek; ketiga dapat ikut andil dalam pengembangan kebijakan dan program.

Evaluasi model CIPP merupakan singkatan dari context, input, process dan product. Pertama context (konteks) merupakan untuk mengidentifikasi kelemahan dan kekuatan beberapa objek seperti institusi, program, target, seseorang serta memberikan arahan untuk perbaikan. Sedangkan pandangan dari Daryanto (Septiyaningrum, 2016) konteks adalah keadaan atau latar belakang yang dapat mempengaruhi jenis-jenis tujuan serta strategi pendidikan yang akan dikembangkan dalam sistem yang berkaitan seperti halnya permasalahan pendidikan, ekonomi, dan pandangan hidup bermasyarakat. Pada intinya evaluasi konteks tersebut menyediakan informasi yang dapat memberikan kontribusi beberapa alternative yaitu setting yang akan ditetapkan, tujuan umum yang akan diupayakan dan sasaran yang akan dicapai. Kedua input (masukan) merupakan untuk ikut membantu dalam mengatur sebuah keputusan, memutuskan sumber yang tersedia, opsi atau alternatif yang dapat diambil, rancangan strategi yang berguna untuk mencapai sebuah tujuan serta proses kerja untuk mencapainya. Stufflebeam berpendapat bahwa unsur-unsur yang berkaitan dengan input (masukan) diantaranya sumber daya manusia, sarana prasarana, anggaran, bahan ajar dan prosedur yang bersangkutan.

Ketiga process (proses), evalausi proses bertujuan untuk memprediksi terkait rancangan alur proses dan rancangan pelaksanaan program selama tahapan implementasi, kemudian menyajikan informasi terkait hasil program dan sebagai arsip prosedur terhadap yang telah terjadi. Pada intinya evaluasi proses diarahkan untuk mengetahui seberapa jauh rencana yang telah dilaksanakan di dalam program, telah terlaksana sesuai dengan rencana dan komponen apa yang perlu diperbaiki. Keempat product (hasil), evaluasi hasil memiliki tujuan untuk menentukam hasil selanjutnya, hasil yang dimaksud ialah baik dari hasil yang telah tercapai atau hasil yang didapat setelah berjalannya program tersebut. pada intinya evaluasi hasil merupakan bentuk penilaian yang dilakukan untuk mengetahui keberhasilan suatu program dalam mencapai tujuan yang telah direncanakan sejak awal.

\author{
Hasil Dan Pembahasan \\ Evaluasi Model CIPP Program English Massive
}


Evaluasi model CIPP yang disampaikan oleh Stufflebeam terdapat 4 aspek yaitu Context, Input, Process dan Product. teori tersebut digunakan untuk menganalisis program English Massive di Kota Kediri pada tahun 2017-2019. Aspek Context terdiri dari latar belakang dan tujuan program serta syarat dan target sasaran. Berdasarkan hasil wawancara, observasi dan dokumentasi bahwasannya latar belakang adanya program $E$ Mas ialah untuk mensukseskan program pemberdayaan masyarakat (Prodamas) dan mendukung program pendidikan, yang dibuat untuk menciptakan atau mempersiapkan sumber daya manusia di Kota Kediri untuk menghadapi persaingan dalam masyarakat ekonomi ASEAN. Tujuan dari program E-Mas ialah untuk meningkatkan daya saing dan membangun kapasitas masyarakat dengan cara memberikan fasilitas pembelajaran terkait pengetahuan dan keterampilan dalam menggunakan bahasa inggris untuk komunikasi. Tentunya untuk dapat mengikuti program E-Mas terdapat beberapa persyaratan yang telah ditetapkan (Kediri, 2016) diantaranya merupakan warga kota Kediri dan tentunya tidak ada batasan usia bagi partisipannya. kemudian persyaratan yang perlu diikuti yaitu pertama jumlah partisipan yang menjadi peserta minimal 10 hingga 20 orang; kemudian yang kedua menunjuk seorang koordinator atau penanggung jawab; yang ketiga usia mulai dari SD 7 tahun hingga dewasa; dan yang keempat mengisi form usulan yang berisi nama kelompok atau spot, nama penanggung jawab, alamat lengkap, jumlah peserta dan waktu belajar kemudian diserahkan ke Dinas Pendidikan Kota Kediri. Untuk target sasaran dalam program ini seluruh warga Kota Kediri dari seluruh kalangan usia. Berdasarkan hasil wawancara dan dokumentasi bahwasannya persyaratan yang ditetapkan termasuk mudah sebab tidak ada ketentuan khusus dan program ini diberikan secara gratis serta target yang ditetapkan oleh Dinas Pendidikan Kota Kediri telah sesuai.

Kemudian aspek Input dalam program English Massive meliputi kesesuaian partisipan, tutor, kualitas materi, anggaran, sarana dan prasarana, dan informasi. pertama kesesuaian partisipan, sesuai dengan tujuan program E-Mas iaah memberdayakan warga Kota Kediri melalui Bahasa inggris maka dari itu perlu adanya partisipasi dari masyarakat, dalam hal ini masyarakat merupakan partisipan program. sesuai dengan target sasaran partisipan program E-Mas ialah seluruh warga Kota Kediri tanpa batasan usia. Kemudian parrtisipan tersebut dibagi menjadi 3 kategori yaitu children, teenager dan adult. berdasarkan hasil wawancara, observasi dan dokumentasi bahwasannya partisipan yang mengikuti telah sesuai denga target yang ditetapkan. Namun ternyata terdapat temuan menarik bahwasannya dari ketiga kategori tersebut jumlah partisipan yang cenderung antusias mengikuti ialah kategori children, berbeda dengan kategori teenager dan adult. 


\section{Cahya dan Bachtiar: "Evaluasi Program English Massive Dalam Upaya Peningkatan Kapasitas Masyarakat di Kota Kediri Tahun 2017-2019"}

\section{Tabel 1}

Jumlah Partisipan English Massive Berdasarkan Kelompok Umur tahun 2017-2019

\begin{tabular}{|l|l|l|l|l|}
\hline & 2017 & 2018 & 2019 & $\begin{array}{l}\text { Jumlah } \\
\text { Total }\end{array}$ \\
\hline Children & 3188 & 2471 & 2226 & 7885 \\
\hline Teenager & 570 & 472 & 342 & 1384 \\
\hline Adult & 260 & 165 & 97 & 522 \\
\hline Jumlah Total & 4018 & 3108 & 2665 & \\
\hline
\end{tabular}

Sumber: Olahan hasil penelitian, (2020)

Berdasarkan Tabel 1, bisa dilihat bahwasannya jumlah partisipan dari kategori children jauh lebih tinggi daripada dengan adult dan teenager. hal tersebut menjadi perhatian bahwasannya program E-Mas diberikan secara gratis namun antusias yang minim dari kategori teenager dan adult. Ternyata berdasarkan hasil temuan saat penelitian bahwasannya penyebab minimnya partisipasi dari kategori teenager dan adult dikarenakan menghadapi kondisi yang kurang mendukung. Seperti halnya permasalahan yang dihadapi teenager bahwasannya mereka tidak banyak cukup waktu dikarenakan mereka sekolah dengan fullday serta memiliki kegiatan lainnya seperti ekstrakulikuler serta les. Sedangkan untuk kategori adult, mereka kebanyakan memiliki kesibukan masing-masing dan sudah berumah tangga.

Kedua tutor, dalam pelaksanaan program E-Mas tentunya diperlukan tutor untuk memberikan materi pembelajaran. Dalam hal ini, Dinas Pendidikan Kota Kediri telah menyediakan tutor melalui proses rekrutmen dan harus memenuhi persyaratan yang telah ditetapkan. Adapun persyaratan rekruten tutor (Kediri, 2020) diantaranya pertama Warga negara Indonesia dengan menunjukkan KTP asli; kedua sanggup untuk ditempatkan diseluruh RT/RW/kelurahan yang tersebar di wilayah Kota Kediri; ketiga usia maksimal 30 tahun dan diutamakan belum menikah; keempat lulusan Strata 1 dari Jurusan Pendidikan Bahasa Inggris atau Sastra Inggris dengan menunjukkan ijazah; kelima pelamar sanggup atau bersedia tidak terikat kontrak dengan pihak lain atau instansi lainnya dalam kurun waktu satu tahun; keenam mampu bekerja full time; dan yang terakhir tidak GAPTEK. Berdasarkan hasil wawancara dan observasi bahwasannya tutor yang disediakan oleh Dinas Pendidikan Kota Kediri telah sesuai dengan kriteria yang ada. Bahkan masyarakat berpendapat bahwa sesuai dengan yang diharapkan.

Namun ternyata terjadi penurunan pada jumlah tutor sejak 2017-2019, berikut data jumlah tutor:

\section{Table 2}

Jumlah Tutor English Massive Tahun 2017-2019 
Tahun

\begin{tabular}{|l|l|}
\hline $\mathbf{2 0 1 7}$ & 57 \\
\hline $\mathbf{2 0 1 8}$ & 50 \\
\hline $\mathbf{2 0 1 9}$ & 39 \\
\hline
\end{tabular}

Sumber: Olahan Hasil Penelitian, (2020)

Dengan menurunnya jumlah tutor tersebut kemudian dibandingkan dengan jumlah partisipan seharusnya tidak mampu mencukupi atau menunjang sebab jumlah partisipan yang cukup banyak sehingga berimbas pada kurang maksimal. Kemudian berdasarkan data yang diperoleh juga bahwasannya jumlah tutor yang menurun berdampak pada menurunnya jumlah partisipan. Berikut data perbandingan jumlah partisipan dengan tutor:

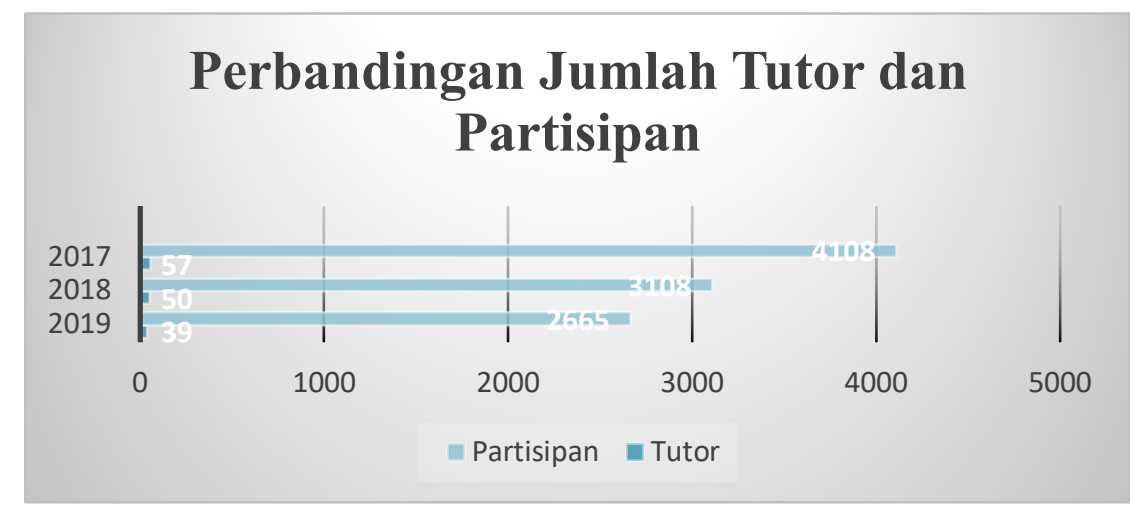

Grafik 2

Perbandingan Jumlah Tutor dan Partisipan

Sumber: Olahan Hasil Penelitian, (2020)

Akan tetapi dengan jumlah tutor yang berbeda jauh dengan jumlah partisipan, berdasarkan hasil wawancara, dokumentasi dan observasi ternyata jumlah tutor mampu menunjang dan mencukupi keberlangsungan program hal tersebut dikarenakan jumlah tutor menyesuaikan jumlah partisipan yang ada.

Ketiga kualitas materi, Materi yang disusun untuk program E-Mas sesuai dengan kurikulum yang ada. Kurikulum tersebut berisi silabus dan satuan acara pembelajaran. Materi yang disampaikan kepada partisipan disesuaikan dengan tingkatan level, tingkatan level tersebut terbagi menjadi 3 yaitu elementary, intermediate dan advanced. Tutor dalam memberikan materi kepada partisipan dibekali dengan modul sehingga materi yang diberikan agar sesuai dengan pokok bahasan. Materi yang diberikan kepada partisipan berfokus pada conversation dan speaking. Berdasarkan hasil wawancara dan observasi bahwasannya tutor dalam menyampaikan materi dibekali modul dan penyampaiannya disesuaikan dengan kemampuan partisipan sehingga partisipan mudah memahami materi. 


\section{Cahya dan Bachtiar: "Evaluasi Program English Massive Dalam Upaya Peningkatan Kapasitas Masyarakat di Kota Kediri Tahun 2017-2019"}

Kualitas materi yang diberikan bagus dan mudah dipahami oleh partisipan. Menariknya, dalam penelitian ini mendapat temuan baru bahwasannya partisipan tidak diberikan modul pembelajaran, yang diberikan hanya tutor saja jika partisipan ingin memiliki modul tersebut maka swadaya sendiri.

Keempat anggaran, anggaran merupakan salah satu bagian penting dalam berlangsungnya suatu program. Anggaran untuk program E-Mas berasal dari APBD Dinas Pendidikan Kota Kediri. berikut jumlah anggaran yang disediakan untuk program E-Mas pada tahun 2017-2019:

\section{Table 3}

Jumlah Anggaran Program English Massive Kota Kediri tahun 2017-2019

\begin{tabular}{|l|l|}
\hline Tahun anggaran & Jumlah anggaran \\
\hline Tahun 2017 & Rp. 3.516 .705 .000 \\
\hline Tahun 2018 & Rp. 3.133 .375 .000 \\
\hline Tahun 2019 & Rp. 2.813 .526 .000 \\
\hline
\end{tabular}

Sumber: Dokumen Pelaksanaan Perubahan Anggaran Satuan Kerja Perangkat Daerah (DPPA SKPD))

Berdasarkan hasil penelitian, anggaran tersebut digunakan untuk operasional kelancaran program E-Mas diantaranya yaitu penggajian tutor dan tim ahli, menyediakan bahan ajar, kemudian kegiatan E-Mas seperti team building, seminar nasional, pelatihan manajemen E-Mas, dan event-event seperti perlombaan contohnya COIN E-Mas. Jika dilihat tabel 3, bahwasannya anggaran yang disediakan sejak tahun 2017 hingga 2019 untuk program E-Mas mengalami penurunan. namun menariknya dengan menurunnya jumlah anggaran setiap tahunnya tersebut masih tetap mampu untuk menunjang keberlangsungan program.

Kelima sarana dan prasarana, program E-Mas di Kota Kediri dilaksanakan di berbagai tempat yang masih dalam lingkup Kota Kediri sebab program ini berada di tingkat RT. Sejak peluncuran program tersebut, tempat tidak menjadi acuan utama dalam pelaksanaan program, pelaksanaan program dapat dilakukan di berbagai tempat seperti balai RT/RW, Musholla, atau dapat juga dilaksanakan di rumah warga. Sehingga untuk tempat tidak ada standar khusus dari Dinas Pendidikan Kota Kediri, lokasi yang digunakan merupakan masyarakat swadaya sendiri. berdasarkan hasil observasi dan hasil wawancara bahwasannya sarana dan prasarana yang ada tersebut telah cukuop memadai dan menunjang keberlangsungan program, sebab untuk lokasi beserta kelengkapan seperti perlengkapan meja dan papan tulis swadaya masyarakat. Sedangkan sarana prasarana yang disediakan oleh Dinas Pendidikan untuk partisipan hanya sebatas Tutor 
dan papan tulis serta modul bagi tutor, papan tulis tersebut jumlahnya tidak banyak sehingga disediakan bagi spot yang tidak memiliki papan tulis.

Keenam informasi, informasi merupakan salah satu unsur penting dalam aspek input. Kejelasan informasi terkait program E-Mas sangatlah penting agar masyarakat mendapatkan informasi yang akurat, sebab apabila informasi yang diberikan tidak jelas maka akan berakibat pada minimnya informasi ke masyarakat sehingga masyarakat minim partisipasi. Berdasarkan hasil penelitian, informasi yang disediakan sudah jelas dan mudah didapatkan. Informasi terkait program E-Mas dapat diakses melalui media sosial, media cetak hingga media internet. Media internet tersebut dapat dilihat melalui website resmi Dinas Pendidikan Kota Kediri, kemudian media sosial melalui Instagram English Massive dan media cetak berupa brosur E-Mas.

Selanjutnya aspek Process dalam Program English Massive meliputi penjadwalan, proses pembelajaran, aktivitas partisipan dan hambatan. Pertama terkait penjadwalan, jumlah spot yang berada di Kota Kediri setiap tahunnya berbeda-beda sehingga tutor dalam mendapatkan jadwal pengajaran tidak hanya satu spot saja melainkan lebih. Dalam proses penjadwalan tersebut dilakukan oleh tutor dan partisipan secara langsung sehingga jadwal yang ditentukan fleksibel dan tidak berbenturan dengan jadwal spot lainnya selain itu juga dapat mengajar dengan maksimal. Berikut data perbandingan antara jumlah spot dengan jumlah tutor pada tahun 2017-2019:

\section{Table 4}

Perbandingan Jumlah tutor dengan jumlah spot tahun 2017-2019

\begin{tabular}{|c|c|c|c|}
\hline Tahun & Tutor & Spot & Tutor : Spot \\
\hline $\mathbf{2 0 1 7}$ & 57 & 153 & $1: 3$ \\
\hline $\mathbf{2 0 1 8}$ & 50 & 175 & $1: 4$ \\
\hline $\mathbf{2 0 1 9}$ & 39 & 169 & $1: 4$ \\
\hline
\end{tabular}

Sumber: Olahan hasil penelitian, (2020)

Jika dilihat pada tabel 4, pada tahun 2017 satu tutor seharusnya mendapatkan 3 spot pengajaran, kemudian pada tahun 2018 hingga 2019 satu tutor mendapatkan 4 spot. Namun pada kenyataannya berdasarkan hasil wawancara dan observasi, satu tutor tersebut dapat mengajar hingga 6 hingga 8 spot bahkan terdapat yg 11 spot. Dalam hal ini berarti dapat disimpulkan bahwa tidak meratanya pembagian jumlah spot pengajaran ke setiap tutor sehingga akan berdampak pada tidak maksimalnya dalam proses penyampaian materi. Disisi lain jadwal yang ditentukan merupakan jadwal yang ditentukan langsung oleh partisipan dan tutor, Dinas Pendidikan Kota Kediri dan Tim Manajemen E-Mas tidak ikut serta dalam menentukan jadwal, sehingga pelaksanaan 


\section{Cahya dan Bachtiar: "Evaluasi Program English Massive Dalam Upaya Peningkatan Kapasitas Masyarakat di Kota Kediri Tahun 2017-2019"}

pembelajaran dilakukan dengan sesuai dengan jadwal yang ditentukan sejak awal. Durasi untuk satu kali pertemuan dalam pembelajaran yaitu 90 menit. Kemudian, dalam proses pembelajaran tentunya terdapat berbagai halangan yang tidak diinginkan mulai dari kondisi yang tidak diinginkan masalah cuaca, atau ada kesibukan dari tutor bahkan tempat pembelajaran yang tidak bisa digunakan. Maka berdasarkan hasil observasi dan wawancara, jika terdapat halangan tutor untuk hadir atau kondisi yang kurang mendukung, tutor memberikan informasi untuk mengganti jadwal pada hari tersebut dengan jadwal yang hari lainnya atau dapat juga mengganti tutor sementara apabila yang berhalangan hadir ialah tutor. sehingga materi pembelajaran yang seharusnya disampikan pada hari tersebut tetap tersampaikan.

Kedua, proses pembelajaran, dalam memberikan materi kepada partisipan tutor menggunakan metode pembelajaran yang berbeda beda-beda sebab menyesuaikan dengan partisipan yang diajarkan karena terdapat 3 level tingkatan. Berdasrkan hasil observasi dan wawancara, metode pembelajaran yang digunakan cukup efektif dengan menggunakan metode diskusi dan fun game, terkadang setiap tutor juga memakai metode jigsaw. Namun perlu ada tambahan media tambahan seperti video dalam pengajaran. Dalam proses pembelajaran tersebut terdapat presensi untuk tutor dan partisipan. Menariknya dalam melakukan absensi, presensi tersebut menggunakan aplikasi sehingga data langsung masuk ke Tim Manajemen English Massive namun juga menggunakan manual juga. Kemudian, Dinas Pendidikan dan Tim Manajemen E-Mas menyediakan wadah untuk mengukur kemampuan partisipan berupa tes. Tes tersebut tidak wajib bagi partisipan namun bagi yang ingin naik ke level yang lebih tinggi maka perlu mengikuti tes yang nantinya akan mendapatkan sertifikat. Tes tersebut dilakukan dalam kurun waktu sekali dalam setahun.

Ketiga aktivitas partisipan, selain belajar Bahasa inggris di spot masing-masing terdapat beberapa kegiatan lainnya yang bertujuan agar partisipan tidak jenuh dalam mengikuti program E-Mas selain itu juga untuk menarik perhatian bagi masyarakat lainnya agar turut serta dalam program tersebut. berdasarkan hasil wawancara dan observasi, kegiatan lainnya yang dilakukan oleh partisipan diantaranya outing class, outbond, learn and play, radio show dan COIN E-Mas.

Keempat hambatan atau kendala, tentunya dalam suatu program yang dijalankan pasti terdapat beberapa kendala atau hambatan yang tidak disangka, meskipun program E-Mas diberikan secara gratis namun program tersebut masih terdapat berbagai kendala yang dihadapi. Berdasarkan hasil wawancara dan observasi, kendala tersebut cukup banyak diantaranya kesadaran masyarakat yang kurang bahwa program E-Mas diberikan secara gratis tapi masyarakat masih banyak yang tidak mengikuti dan tidak termotivasi 
sebab mereka menganggap jika tidak ikut masyarakat tidak kehilangan apapun; lokasi spot yang berbeda-beda terkadang menyebabkan kurang kondusif sebab sejak awal tidak ada ketentuan khusus untuk tempat pembelajaran maka bisa dilakukan di teras rumah, balai RT; kurang kooperatifnya penanggung jawab spot sehingga tutor bekerja dengan ekstra untuk merangkul atau memotivasi partisipannya; modul yang disediakan tidak dibagikan dengan partisipan namun modul diberikan kepada tutor saja; kemudian terkendala jarak yang jauh antara lokasi tempat tinggal tutor dengan spot pembelajaran, kemudian kesibukan masyarakat, dan yang terakhir honor yang tidak cair tiap bulan.

Dan yang terakhir aspek Product program Engslish Massive meliputi dampak yang ditimbulkan setelah adanya program seperti kemampuan partisipan meningkat. Berdasarkan hasil wawancara dan observasi, kemampuan meningkat dirasakan oleh para partisipan sehingga mereka menjadi lebih percaya diri untuk berbicara menggunakan Bahasa inggris. hal tersebut terbukti ketika perwakilan dari partisipan E-Mas mendapatkan prestasi dalam 2 kategori lomba yang diadakan oleh PEACE CORPS se Jawa Timur. Dari 10 partisipan yang dikirim untuk mengikuti perlombaan, dua partisipan mendapatkan juara 6. Selain kemampuan partisipan yang meningkat, dampak dirasakan oleh tutor juga yaitu mendapatkan lapangan pekerjaan dan meningkatkan skill sebab tutor mengikuti workshop yang diselenggarakan oleh E-Mas.

Meningkatnya kemampuan partisipan tersebut juga memberikan dampak positif bagi Kota Kediri. hal tersebut dilihat dari meningkatnya IPM Kota Kediri dalam beberapa tahun terakhir. Alhasil pada data terakhir yaitu tahun 2018, IPM Kota Kediri mencapai 77,58. Berikut data Indeks Pembangunan Manusia di Kota Kediri sejak tahun 2015-2018:

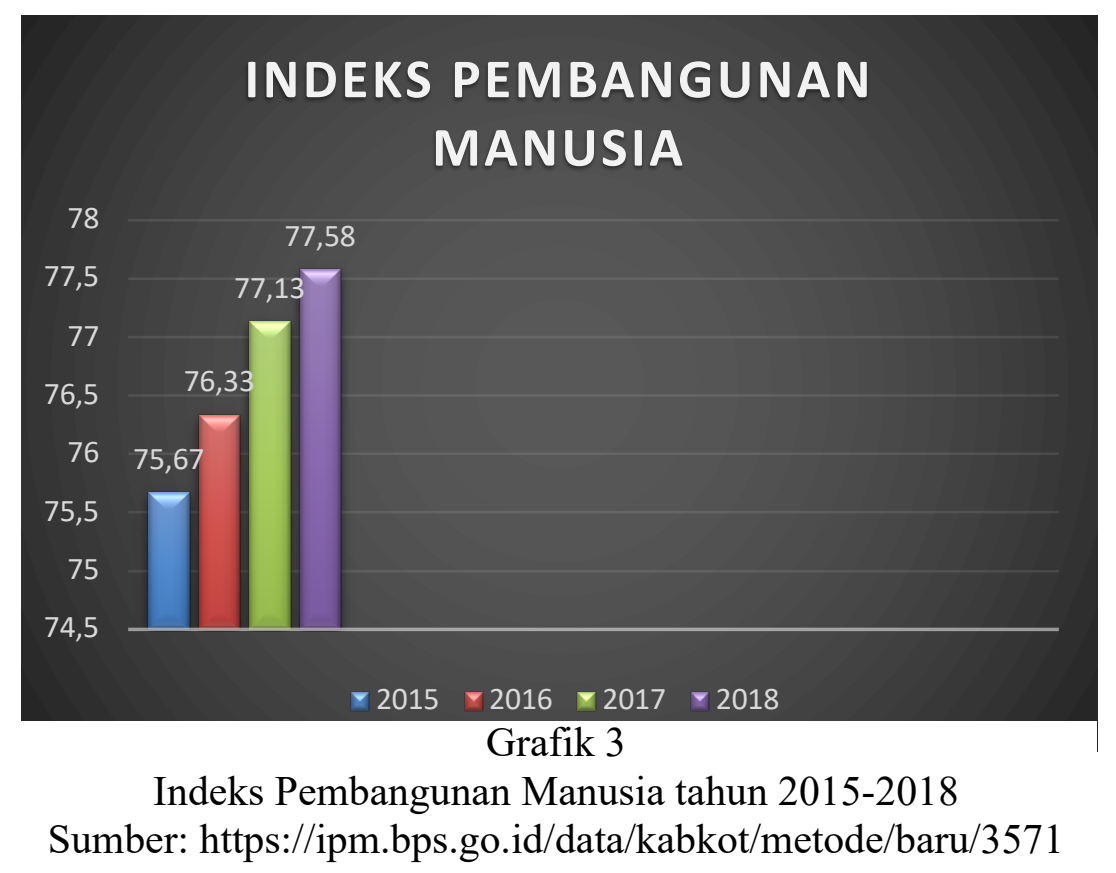




\section{Cahya dan Bachtiar: "Evaluasi Program English Massive Dalam Upaya Peningkatan Kapasitas Masyarakat di Kota Kediri Tahun 2017-2019"}

\section{Faktor Pendukung dan Penghambat Program English Massive}

Berdasarkan analisis dan data yang didapatkan, terdapat beberapa faktor pendukung dan penghambat dalam pelaksanaan program. Faktor pendukung program E-Mas diantaranya pertama persyaratan Program E-Mas yang mudah dan gratis, sebab sesuai dengan tujuan dalam program E-Mas pemerintah Kota Kediri ingin meningkatkan daya saing dan kapasitas masyarakat Kota Kediri. Oleh karena itu, Pemerintah Kota Kediri memberikan pelatihan atau pemberdayaan melalui pembelajaran Bahasa inggris melalui program E-Mas yang diberikan secara gratis dan syarat yang mudah yaitu dengan partisipan yang tidak ada batasan usia, serta lokasi dapat dilakukan dimana saja; kedua penyampaian materi sesuai dengan silabus pada modul, Dalam menyampaikan materi selama pelaksanaan pembelajaran, tutor menggunakan modul yang disediakan oleh Tim Manajemen E-Mas. Dalam modul terdapat silabus yang berisi materi-materi selama satu term. Tutor memberikan materi berdasarkan silabus sehingga materi yang disampaikan sesuai dengan yang direncanakan dan tersampaikan tepat waktu bahkan sesuai juga dengan kemampuan partisipan.

Ketiga informasi yang jelas, informasi program E-Mas pertama disampaikan melalui sosialisasi oleh Pemerintah Kota Kediri. Selain melalui sosialisasi, informasi dapat diakses melalui media sosial, internet hingga cetak. hal ini mempermudah bagi masyarakat untuk mengakses informasi dimana dan kapanpun saja. informasi dapat diakses melalui Instagram E-Mas, website E-Mas, dan brosur E-mas; Keempat menentukan jadwal dilakukan oleh tutor dan partisipan, jadwal setiap spot berbeda-beda sebab jumlah spot yang cukup banyak. Dalam menentukan jadwal pembelajaran jadwal ditentukan oleh Tutor dan Partisipan secara langsung, sehingga jadwal pelaksanaan pembelajaran dapat terlaksana sesuai dengan yang diinginkan partisipan dan jelas karena tutor dan partisipan koordinasi secara langsung; Kelima metode pembelajaran cukup efektif dan presensi menggunakan aplikasi, Tutor dalam menyampaikan materi menggunakan metode pembelajaran seperti diskusi, jigsaw dan fun game. Metode yang digunakan oleh tutor tersebut telah cukup efektif untuk menyampaikan materi sehingga partisipan dapat menerima materi dengan mudah. Kemudian dalam proses pelaksanaan, program E-Mas terdapat presesnsi untuk tutor dan partisipan. Saat ini presensi dilakukan melalui aplikasi dan juga manual.

Selanjutnya faktor penghambat program E-Mas diantaranya yaitu pertama kurangnya kesadaran masyatakat, program E-Mas merupakan program pembelajaran 
Bahasa inggris secara gratis. Namun dengan gratis tidak menjamin antusias masyarakat yang tinggi melainkan jumlah partisipan E-Mas malah menurun. Hal ini disebabkan karena kurangnya rasa kesadaran dan motivasi dari masyarakat sendiri terkait program ini. Mereka tidak merasa kehilangan apapun jika tidak mengikuti program tersebut dikarenakan program tersebut diberikan secara gratis; kedua kesibukan masyarakat, kesibukan masyarakat berimbas pada sedikitnya jumlah partisipan dari remaja dan dewasa. Untuk remaja, mereka terbentur dengan kondisi aktivitas lain seperti les, ekstrakulikuler, penerapan fullday sehingga merasa tidak ada waktu. Kemudian orang dewasa, mereka memiliki kesibukan bekerja dan mengurus rumah; ketiga terkendala jarak yang jauh antara tempat tinggal Tutor dan lokasi spot pembelajaran sebab spot pembelajaran yang banyak dan tersebar di seluruh daerah di Kota Kediri. Tutor E-Mas tidak hanya berasal dari Kota Kediri saja melainkan dari luar daerah juga ada. Jarak yang jauh antara spot dengan tempat tinggal tutor menjadi kendala dalam program ini. Hal ini berdampak keberlangsungan program apabila kondisi yang tidak memungkinkan terjadi seperti cuaca tidak mendukung sehingga tutor mengganti jadwal dan sementara off.

Keempat Kondisi sarana prasarana setiap spot cenderung kurang lengkap serta terkadang tidak kondusif, ketentuan untuk sarana dan prasarana pembelajaran Program E-Mas memang tidak ada. Setiap spot dapat melakukan pembelajaran dimana saja dengan sarana yang ada. Dengan tidak ada ketentuan khusus tersebut berdampak pada kurang kondusifnya lokasi yang digunakan. Seperti halnya cuaca kurang mendukung sehingga mengganggu proses pembelajaran. Kemudian sarana prasarana setiap spot yang berbedabeda dan terkadang tidak lengkap juga menyebabkan tidak berjalan semestinya; kelima partisipan tidak diberi Modul pembelajaran, modul yang tersedia hanya dapat diakses oleh tutor saja. Partisipan tidak diberikan modul pembelajaran, apabila ingin memiliki modul partisipan swadaya sendiri. hal tersebut berdampak pada partisipan yang tidak dapat mengulang materi yang diajarkan saat pembelajaran karena mereka tidak memiliki modul; keenam jumlah Anggaran yang menurun, anggaran merupakan komponen penting dalam berjalannya sebuah program. Jumlah anggaran yang disediakan untuk program EMas cenderung menurun setiap tahunnya. Menurunnya anggaran untuk program E-Mas menyebabkan honor atau penggajian tutor tidak cair tiap bulan.

Ketujuh terdapat Penanggung Jawab yang kurang kooperatif, Dukungan masyarakat sangat penting untuk berjalannya program ini semestinya. Namun dalam pelaksanaannya tutor bekerja lebih untuk mengingatkan partisipan. Tutor bekerja lebih dikarenakan terkadang ada penanggung jawab dari spot kurang kooperatif atau kurang bisa diajak koordinasi, hal tersebut berimbas pada pembelajaran yang tidak maksimal; kedelapan jumlah tutor menurun, Tutor merupakan komponen penting untuk proses 


\section{Cahya dan Bachtiar: "Evaluasi Program English Massive Dalam Upaya Peningkatan Kapasitas Masyarakat di Kota Kediri Tahun 2017-2019"}

pembelajaran sebab dengan adanya tutor materi dapat tersampaikan. Tentunya dengan jumlah spot yang banyak perlu diimbangi dengan jumlah tutor juga. Namun dalam pelaksanaannya jumlah tutor mengalami penurunan dan berimbas pada tidak maksimalnya penyampaian materi. Hal tersebut dikarenakan satu tutor medapatkan jumlah spot hingga 6-8 spot.

\section{Penutup}

Berdasarkan hasil penjabaran dan analisis diatas maka dapat ditarik kesimpulan bahwasannya program E-Mas di Kota Kediri yang diselenggarakan oleh Dinas Pendidikan Kota Kediri telah terlaksana cukup baik namun masih terdapat beberapa aspek yang perlu adanya perbaikan dan peningkatan. Hal tersebut dapat dilihat melalui beberapa aspek sebagai berikut: pertama, aspek Context meliputi latar belakang program E-Mas yaitu untuk mensukseskan program pemberdayaan masyarakat (Prodamas) dengan cara memberdayakan masyarakatnya melalui pembelajaran Bahasa inggris; tujuan program E-Mas ialah mempersiapkan sumber daya manusia di Kota Kediri dengan cara meningkatkan daya saing dan membangun kapasitas masyarakat melalui belajar Bahasa inggris agar mendapatkan pengetahuan dan keterampilan Bahasa inggris. syarat untuk mengikuti program E-Mas tergolong mudah dan target sasaran program tersebut ialah seluruh masyarakat Kota Kediri. Kedua, aspek Input meliputi kesesuaian partisipan program E-Mas telah sesuai dengan target dan partisipan yang cenderung tinggi ialah children; tutor disediakan oleh Dinas Pendidikan Kota Kediri telah sesuai dengan kriteria dan harapan masyarakat namun terdapat penurunan jumlah tutor; kualitas materi sudah bagus dan mudah dipahami sebab sesuai dengan silabus dan disesuaikan dengan partisipan namun modul tidak diberikan kepada partisipan; anggaran program $E$ Mas menurun namun mampu mencukupi untuk operasional pelaksanaan program; sarana dan prasarana E-Mas cukup memadai dikarenakan dikelola secara swadaya masyarakat sedangkan dari Dinas Pendidikan hanya sebatas tutor, papan tulis dan modul untuk tutor; informasi program E-Mas sudah jelas dapat diakses melalui website resmi Dinas Pendidikan Kota Kediri dan media sosial E-Mas.

Ketiga aspek Process meliputi penjadwalan program E-Mas telah sesuai dan fleksibel dengan durasi untuk satu pertemuan 90 menit, namun pembagian jumlah spot ke setiap tutor tidak merata sehingga berdampak pada tidak maksimal; proses pembelajaran terdiri dari metode pembelajaran yang digunakan tutor cukup efektif namun perlu ada tambahan media pembelajaran, kemudian dalam pembelajaran terdapat presensi dengan menggunakan aplikasi serta manual dan disediakan tes bagi partisipan namun tidak wajib; aktivitas partisipan selain pembelajaran ialah outbond, outing class, COIN E-MAS, learn and play hal tersebut bertujuan untuk membuat partisipan tidak jenuh; hambatan dalam program E-Mas ialah kurangnya kesadaran masyarakat, 
kesibukan bagi orang dewasa dan remaja, saran prasarana yang kurang kondusif, kurnag kooperatifnya PJ, terkendala jarak yang jauh lokasi pembelajaran, modul tidak diberikan kepada partisipan dan honor terkadang tidak cair tiap bulan.

Keempat aspek product meliputi dampak dari adanya program yaitu kemampuan partisipan meningkat dalam berbahasa inggris sehingga memperoleh prestasi dalam perlombaan. Perwakilan partisipan E-Mas memperoleh juara 6 dalam 2 kategori lomba yang diadakan oleh PEACE CORPS se Jawa Timur. Selain itu, meningkatnya kemampuan partisipan tersebut berdampak pada meningkatnya indeks pembangunan manusia (IPM) di Kota Kediri. kemudian berdasarkan beberapa aspek tersebut maka terdapat faktor pendukung dan penghambat dalam program E-Mas. Faktor pendukung program E-Mas diantaranya persyaratan yang mudah dan gratis; penyampaian materi sesuai dengan silabus pada modul; informasi yang jelas terkait program E-Mas; menentukan jadwal dilakukan oleh tutor dan partisipan secara langsung sehingga jadwal jelas; metode pembelajaran cukup efektif dan presensi kegiatan menggunakan aplikasi.

Selanjutnya faktor penghambat program E-Mas diantaranya kurangnya kesadaran masyarakat; kesibukan masyarakat sehingga banyak yang tidak ikut; terkendala jarak jauh antara tempat tinggal tutor dan lokasi spot; kondisi sarana prasarana setiap spot yang berbeda-beda cenderung terkadang kurang lemgkap sehingga berdampak kurang kondusif; partisipan tidak diberi modul pembelajaran; jumlah anggaran yang menurun; terkadang terdapat penanggung jawab yang kurang kooperatif; jumlah tutor yang menurun sehingga berdampak pada tidak maksimalnya dalam memberikan materi.

Rekomendasi untuk program English Massive di Kota Kediri diantaranya, pertama perlu adanya sosialisasi kembali agar masyarakat tergerak dan memiliki semangat untuk mengikuti; kedua dalam pembagian spot Dinas Pendidikan Kota Kediri melakukan pengelompokan antara tutor dan spot berdasarkan jarak yang ditempuh; Dinas Pendidikan Kota Kediri menyediakan modul untuk partisipan; anggaran ditingkatkan terutama untuk sarana dan prasaran serta gaji tutor; Dinas Pendidikan Kota Kediri melakukan pembatasan terkait jumlah spot yang diajar dengan maksimal 4 spot; perlu ditetapkan kriteria-kriteria yang harus dipenuhi sebelum menentukam lokasi; perlu adanya koordinasi secara berkesinambungan antara penyelenggara program dan penanggung jawab selaku partisipan agar berjalan dengan sesuai. 


\section{Cahya dan Bachtiar: "Evaluasi Program English Massive Dalam Upaya \\ Peningkatan Kapasitas Masyarakat di Kota Kediri Tahun 2017-2019"}

\section{Daftar Pustaka}

Agustino, L. (2017). Dasar-dasar Kebijakan Publik Edisi Revisi. Bandung: Alfabeta.

Diah, M. P. (2018). English Massive Program: A Breakthrough to face the ASEAN Econmic Community. Advances in Economics, Business and Management Research.

First, E. (2019). EF EPI Kecakapan Bahasa Inggris EF: Peringkat 100 Negara dan Wilayah menurut Kecakapan Berbahasa Inggris . Education First.

Islamy, M. I. (2009). Prinsip-prinsip perumusan kebijaksanaan negara. Jakarta: Bumi Aksara.

Kediri, D. P. (2016). Home. Retrieved Apri 14, 2020, from Dinas Pendidikan Kota Kediri: http://pendidikan.kedirikota.go.id/emas/

Kediri, D. P. (2020). Rekrutmen Tutor English Massive 2020. Retrieved April 14, 2020, from Dinas Pendidikan Kota Kediri: http://pendidikan.kedirikota.go.id/emas/rekruitmen-tutor-english-massive-2020/

Nugroho, R. (2017). Public Policy. Jakrta: PT Elex Media Komputindo.

Rusdiana, H. A. (2017). Manajemen Evaluasi Program Pendidikan: Konsep, Prinsip dan Aplikasinya di Sekolah/Madrasah (1st ed.). Bandung: Pusaka Setia.

Septiyaningrum, A. (2016). Implementasi Model Evaluasi CIPP Pada Pelaksanaan Program Pendidikan dan Pelatihan di BPTT Darman Prasetyo Yogyakarta. Skripsi.

Setiawan, A. A. (2018). Metodologi Penelitian Kualitatif(1st ed.). Sukabumi: CV Jejak.

Stufflebeam, D. (1985). Systematic Evaluation: A self-instrumental guide to theory and practice. Boston: Kluwer-Nijhoff Publishing.

Suwendra, I. W. (2018). Metodologi Penelitian Kualitatif(1st ed.). Bali: Nilacakra. 